\title{
Reduction of Heavy Metals in Squid, Green Mussels, White Shrimp Using Combination of Saccharomyces cerevisiae and Candida albicans
}

\author{
Adolf J. N. Parhusip ${ }^{1}$ Trifena A. Wijaya ${ }^{1}$ Wahyu Irawati ${ }^{2, *}$ \\ ${ }^{1}$ Laboratory of Food Technology Study Program, Universitas Pelita Harapan. M.H. Thamrin Boulevard 1100, \\ Lippo Karawaci, Tangerang, Indonesia \\ ${ }^{2}$ Department of Biology Education, Faculty of Education, Universitas Pelita Harapan. M.H. \\ Thamrin Boulevard 1100, Lippo Karawaci, Tangerang 15811, Banten, Indonesia \\ *Corresponding author. Email: w.irawati3@gmail.com
}

\begin{abstract}
The area of Muara Angke waters, Cituis waters in Tangerang, and Indramayu waters found various activities, such as industry, fish auction sites, and ship ports which are sources of heavy metal contamination. Pollution of heavy metals at sea due to industrial waste can disrupt marine life that lives in these waters. Marine biota such as squid, green mussels and white shrimp can accumulate heavy metals in their bodies. Bioremediation is a process carried out to reduce heavy metals biologically using microorganisms. Microorganisms that can be used as bioremediation agents are yeast Saccharomyces cerevisiae and Candida albicans obtained from the Indonesian Culture Collection, LIPI Cibinong. Yeast combination of $\quad$ S. cerevisiae and C. albicans can increase levels of heavy metal reduction. The purpose of this study is to determine the best yeast combination in reducing the content of heavy metals and to determine the highest metal content. In the main study, the treatment of the yeast combination was a factor with nine level variations, to see the decline of heavy metals in the sample. Analysis of heavy metal content in samples was analyzed using the Atomic Absorption Spectrophotometer. The main research results showed that the largest percentage of copper reduction in squid samples was combination treatment of $\quad$ S. cerevisiae: C. albicans $(60 \%: 40 \%)$ by $94.66 \%$. In green mussels of $90.74 \%$ with $S$. cerevisiae (100\%) and in white shrimp with combination of S. cerevisiae:C. albicans (40\%:60\%) of 77, 92\%.
\end{abstract}

Keywords: Candida albicans, combination, heavy metals, marine biota, Saccharomyces cerevisiae

\section{INTRODUCTION}

Indonesia is a maritime country, which is a country where most of its territory is water, some of them are Muara Angke waters in Jakarta Bay, Cituis waters in Tangerang, and Indramayu waters. In these waters, there are various types of activities such as industry, fishing grounds, and ship ports. This causes the waters of Cituis, Muara Angke, and Indramayu to become a gathering place for pollutants from factory waste and waste originating from human activities. One of the pollutants is heavy metal [1].

Pollution of heavy metals in the waters can disrupt marine life. Basically, marine biota has the ability to accumulate heavy metals and will continue to be stored for a long time [2]. According to [3], heavy metals will accumulate through the food chain and the higher the level of the food chain, the accumulation of heavy metals in the body will also increase. This is evidenced by the levels of sediment in waters that are polluted by heavy metals having a higher heavy metal content compared to the levels of heavy metals in water [4].

Marine biotas such as squid, green mussels, and white shrimp are widely consumed by Indonesian people because of their high protein content, and are easily found in Indonesian waters. Pollution of waters makes squid, green mussels, and white shrimp accumulate heavy metals in their bodies and have exceeded the maximum limit set by SNI 7387-2009 and BPOM 2018 [5-8]. Consumption of heavy metals can interfere with human health, such as damage to 
the formation of red blood cells, damage to the kidneys, liver, heart, and blood system. Heavy metals will settle and will accumulate in the body, causing long-term effects [9].

In minimizing the influence of heavy metals, biological methods are used that can reduce levels of heavy metals, such as bioremediation. Bioremediation is the process of reducing heavy metals in contaminated soils and waters using organisms, such as bacteria, yeast, and algae [10]. Yeast is able to accumulate heavy metals to various levels under various external conditions [11]. Yeast Saccharomyces cerevisae and Candida albicans are heavy metal resistant yeasts.

In this study, the best combination ratio of the two yeasts will be determined in reducing the content of heavy metals found in squid, green mussels, and white shrimp samples. Samples were obtained from Cituis waters in Tangerang, Muara Angke waters in Jakarta Bay, and Indramayu waters.

\section{METHODS}

\subsection{Equipment and Materials}

The study was done in Laboratory of Food Technology Study Program, Universitas Pelita Harapan, in 2020. The equipment used the research were ovens, pans, knives, cutting boards, plastic containers, "Cosmos" dry blenders, analytical scales, table scales, tablespoons, spatulas, ose seals, screw tubes, erlenmeyers, beaker glass, measuring cups, pipette Mohr, glass bottles, watch glass, bulp pumps, magnetic stirrers, aluminum foil, glass funnels, filter paper, stirring rods, heaters, glass preparations, cover glass, disposable petri dishes, micropipettes, tip pipettes, bunsen, lighters, vortex, microscope, incubator, autoclave, laminar air flow, fume hood, refrigerator, colony counter, shaker "Thermo SCIENTIFIC", Atomic Absorption Spectrophotometer (AAS) "AA-6800 Shimadzu".

The materials used in this study were squid, green mussels, and white shrimp obtained from Muara Angke Fish Auction Place, Tangerang Cituis waters, and Indramayu waters, Saccharomyces cerevisae culture and Candida albicans culture obtained from Indonesian Culture Collection (InaCC), LIPI Cibinong, and Potato Dextrose Agar (PDA) media, Potato Dextrose Broth (PDB) media, $65 \%$ nitric acid $\left(\mathrm{HNO}_{3}\right), 30 \%$ hydrogen peroxide $\left(\mathrm{H}_{2} \mathrm{O}_{2}\right)$, aquades, and malachite green.

\subsection{Making Stock Culture and Work Culture}

Pure cultures cultures of Saccharomyces cerevisiae and Candida albicans were inoculated into $10 \mathrm{ml}$ of sterile PDB, then incubated at $25^{\circ} \mathrm{C}$ (room temperature) for 24 hours. After being incubated for 24 hours, each yeast culture was inoculated 1 ose into a screw tube containing oblique PDA media and incubated at $25{ }^{\circ} \mathrm{C}$ for 24 hours into a stock culture. Work culture was made by taking 1 ose of stock culture and inoculated into $10 \mathrm{~mL}$ PDB then incubated at $25^{\circ} \mathrm{C}$ for 24 hours.

\subsection{Yeast Identification}

Yeast identification is done macroscopically by looking at colonies growing on the PDA medium. Microscopic observations were made using a microscope to see yeast characteristics, such as the formation of budding, cell shape, and cell size. Observations were made by making culture preparations on the slide and dripping with malachite green dye, then covered with a glass cover and viewed under a microscope at magnification 1000 times.

\subsection{Determination of the Yeast Growth Curves}

$1 \mathrm{ml}$ of work culture was inoculated into $9 \mathrm{~m}$ of PDB and incubated at $25^{\circ} \mathrm{C}$ for 24 hours. Growth and increase in the number of yeasts were observed every 0 , Samples in the form of squid, green mussels, and white shrimp were cleaned first, then the samples are dried in an oven at $105^{\circ} \mathrm{C}$. After drying the sample in a dry blender until homogeneous, then the samples were weighed as much as 3 grams and carried out wet destruction with concentrated acid, in the form of $\mathrm{HNO}_{3}(65 \%)$ and $\mathrm{H}_{2} \mathrm{O}_{2}(30 \%)$ with a ratio of $1: 1$. The sample was then heated using a heater at $350^{\circ} \mathrm{C}$ for 15 minutes while stirring using a magnetic stirrer to obtain a homogeneous mixture. The completion of wet digestion was marked by a clear solution and the sample is ready to be measured with AAS.

$2,4,6,8,10,12,24$, and 48 hours by counting the colonies that grow on PDA. The growth pattern was observed using spectrophotometer with wavelength of $600 \mathrm{~nm}$. The results obtained were plotted into the growth curve with y as a log of the number of yeast and $\mathrm{x}$ as time. 


\subsection{Research Procedures}

\subsubsection{Preliminary Research}

Samples in the form of squid, green mussels, and white shrimp were cleaned first, then the samples are dried in an oven at $105^{\circ} \mathrm{C}$. After drying the sample in a dry blender until homogeneous, then the samples were weighed as much as 3 grams and carried out wet destruction with concentrated acid, in the form of $\mathrm{HNO}_{3}(65 \%)$ and $\mathrm{H}_{2} \mathrm{O}_{2}(30 \%)$ with a ratio of 1: 1 . The sample was then heated using a heater at $350^{\circ} \mathrm{C}$ for 15 minutes while stirring using a magnetic stirrer to obtain a homogeneous mixture. The completion of wet digestion was marked by a clear solution and the sample is ready to be measured with AAS.

\subsubsection{Heavy Metal Content Test}

Samples (squid, green mussels, white shrimps) that have been destructed with concentrated acid, will be analyzed for heavy metal content using Atomic Absorption Spectrophotometer (AAS). The wavelengths used are in accordance with the analyzed heavy metals, namely lead $(\mathrm{Pb})$, cadmium $(\mathrm{Cd})$, copper $(\mathrm{Cu})$, and chromium $(\mathrm{Cr})$ with wavelengths of $283.3 \mathrm{~nm}$ each; $228.8 \mathrm{~nm} ; 324.7 \mathrm{~nm} ; 425.4 \mathrm{~nm}$, respectively.

\subsection{Main Research}

\subsubsection{Reduction of Heavy Metal Content}

The test for the reduction of heavy metal content was done by mixing samples, GDP media, and yeast combinations which will then be shaken using a shaker speed of $170 \mathrm{rpm}$ at $25{ }^{\circ} \mathrm{C}$. Yeast combination consists of 9 levels, that was: $S$. cerevisiae (100\%):_C. Albicans (100\%); S. cerevicae: C. albicans (50\%:50\%); S. cerevicae: C. albicans (60\%:40\%); S. cerevicae: C. albicans (40\%:60\%); S.cerevicae: C. albicans (70\%:30\%); S.cerevicae: C. albicans $(30 \%: 70 \%) ; \quad$ S. cerevicae:C. albicans (80\%:20\%); and S. cerevicae: C. albicans (20\%:80\%). The resulting mixture will be destructed using concentrated acid, in the form of $\mathrm{HNO}_{3}(65 \%)$ and $\mathrm{H}_{2} \mathrm{O}_{2}(30 \%)$ in a ratio of 1 : 1 . Samples that have been destructed will be tested for final heavy metal content with an Atomic Absorption Spectrophotometer (AAS) at the wavelength of each heavy metal. Reduction in heavy metal content was the difference between initial heavy metal content and heavy metal content after contact with heavy metal resistant yeast.

\subsubsection{Total Yeast Resistant Heavy Metal}

Total yeast resistant heavy metals were calculated using the Total Plate Count (TPC) method on a mixture of PDB media, fine samples, and a combination of yeast that had been incubated at $25^{\circ} \mathrm{C}$ for 24 hours using a shaker with a speed of $170 \mathrm{rpm}$. The mixture was pipetted as much as $1 \mathrm{ml}$ and then put in a diluent tube containing $9 \mathrm{ml}$ of $0.85 \%$ physiological saline $(\mathrm{NaCl})$ solution that has been sterile. Dilution was carried out up to $10^{-7}$ and fertilization was carried out at the three highest dilution levels by taking as much as $1 \mathrm{~mL}$ and poured into a sterile petri dish.

The petri dish was then poured with PDA media, then flattened by shaking like the number eight and allowed to solidify. The cup was incubated at $25{ }^{\circ} \mathrm{C}$ (room temperature) for 24 hours, then the growing colonies were counted using a colony counter as the number of yeast resistant heavy metals. The formula for calculating the total yeast resistant heavy metals in a sample is as follows.

$\mathrm{N}=\sum \mathrm{c}[(1 \mathrm{x} 1)+(0,1 \times \mathrm{n} 2)] \mathrm{xd}$

Note:

$\mathrm{N}=$ total yeast colony in the sample $(\mathrm{CFU} / \mathrm{mL})$

$\sum \mathrm{c}=$ the number of colonies in all plates counted (range 25-250)

$\mathrm{n}_{1} \quad=$ the number of plates in the first dilution calculated

$\mathrm{n}_{2} \quad=$ the number of plates in the second dilution calculated

$\mathrm{d} \quad=$ first calculated dilution

\subsubsection{Heavy Metal Inhibition Activity Test}

Heavy metal inhibition activity test was carried out by the well diffusion method which aims to see the resistance of yeast to the heavy metals contained in the sample. The combination of yeast according to treatment was 5\% mixed with PDA media and allowed to stand until the media hardens. Media that has been hardened given a hole resembling a well at three points with a diameter of $6 \mathrm{~mm}$. Each well was filled with fine samples, namely squid, green mussels, and white shrimp. The media was incubated at $25^{\circ} \mathrm{C}$ for 24 hours. The ability of yeast combination was seen when no clear zone is formed around the test sample.

\subsubsection{Experimental Design}

The preliminary study was designed using a completely randomized design (CRD) of 1 factor and 
3 repetitions. The main research to determine the best combination treatment that can reduce the content of heavy metals in the sample. The experimental design used in this study was a factorial Completely Randomized Design (CRD) with nine level variations.

\section{RESULT AND DISCUSSION}

\subsection{Identification of Yeast Culture}

Morphological identification of $\mathrm{S}$. cerevisiae and C. albicans culture using malachite green dye which was then observed using a microscope with magnification 1000 times. Yeast cultures of S. cerevisiae and C. albicans have an oval shape and form buds (budding). The yeast characteristics of S. cerevisiae are in accordance with the statement of [12], which has round cells and reproduces by budding. Yeast $\mathrm{C}$. albicans has an oval cell shape and multiply by budding, this shows the suitability of the characteristics shown by yeast $\mathrm{C}$. albicans [13].

\subsection{Yeast Culture Growth Curve}

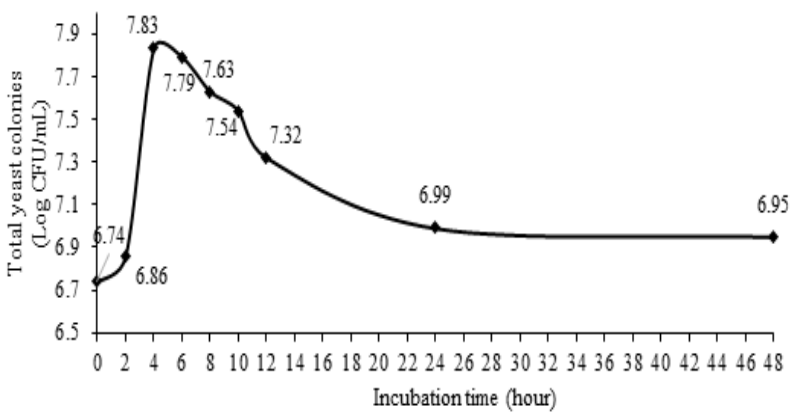

Figure 1. Growth curve of Saccharomyces cerevisae

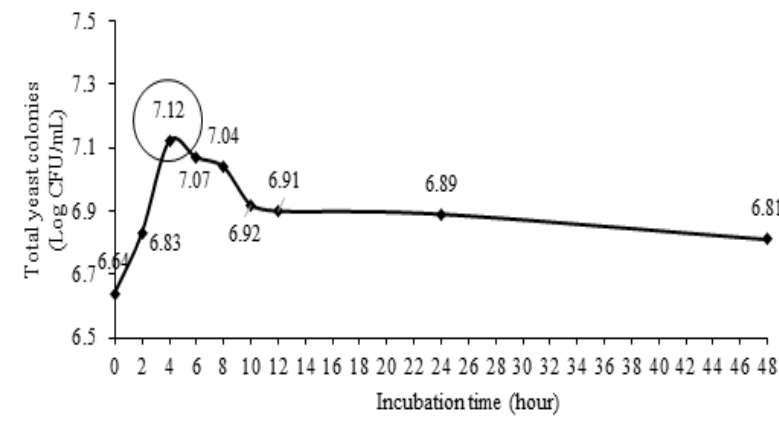

Figure 2. Growth curve of Candida albicans

Growth curve showed the life phase of a microorganism which included the adaptation phase, log or exponential phase, stationary phase, and death phase [14]. Growth curves were obtained by growing yeast cultures on Potato Dextrose Agar (PDA) medium incubated at $25^{\circ} \mathrm{C}$ for 24 hours. The number of yeasts was added at $0,2,4,6,8,10,12,24$, and 48 hours. The number of yeasts obtained per hour of observation was calculated using the new method in units of $\mathrm{CFU} / \mathrm{mL}$, then it will be converted to $\mathrm{CFU}$ $\log / \mathrm{mL}$. The $\log \mathrm{CFU} / \mathrm{mL}$ values obtained will be plotted into a curve which can be seen in Figure 1.

The growth curves of S. cerevisiae and C. albicans have a fairly short adaptation phase, ie the 0th hour to the 2nd hour, can be seen in Figure 1 and 2 that the speed of the adaptation phase is determined by the number of cells inoculated, the appropriate physiological and morphological conditions, and the cultivation media needed (14). The number of yeast cells of $\mathrm{S}$. cerevisiae at 0 hours was $5.55 \times 106 \mathrm{CFU} / \mathrm{mL}$ and increased to $7.30 \times 106 \mathrm{CFU} / \mathrm{ml}$ after 2 hours of incubation. Yeast C. albicans had a cell count of $4.40 \times 106 \mathrm{CFU} / \mathrm{ml}$ at the 0th hour and at the second hour the number of cells increased to 6.75x106 CFU/ml. Yeast S. cerevisiae and C. albicans entered the exponential phase at the 4th hour, with a total cell count of $6.75 \times 107 \mathrm{CFU} / \mathrm{ml}$ and $1.33 \times 107 \mathrm{CFU} / \mathrm{ml}$ respectively. The exponential phase is the phase of increasing activity or increasing the number of cells after the adaptation phase because microbes divide rapidly and constantly. In the exponential phase there are several factors that influence, including nutrient content in the growth medium, temperature, and $\mathrm{pH}[15]$.

The next phase was experienced yeast $\mathrm{S}$. cerevisiae and C. albicans is a stationary phase, because there is no increase in the number of cells after the 4th hour. Stationary phase was a phase that shows the balance between the growth of microbes with dead microbes, thus showing a flat curve shape. In the stationary phase, the cell size become smaller because it was still dividing even though nutrients in the media had started to run out. Stationary phase of the yeast of S. Cerevisae and C. Albicans was from 6 to 48 hours [16].

\subsection{Analysis of Initial Heavy Metal Content Test Result}

Samples of squid, green mussels and white shrimp obtained from TPI Muara Angke, Cituis Tangerang waters, and Indramayu waters that have been mashed will be distructed using strong acids. 


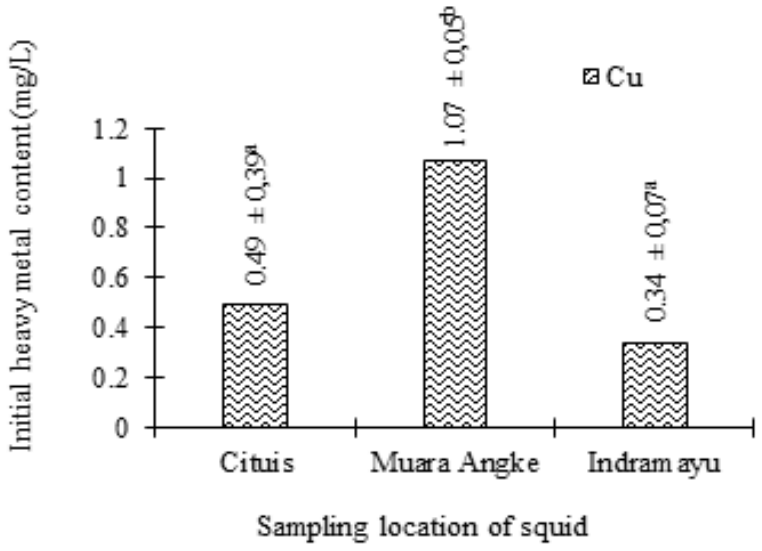

Figure 3 The initial heavy metal content of copper $(\mathrm{Cu})$ in squid samples obtained from Cituis waters, TPI Muara Angke, and Indramayu waters
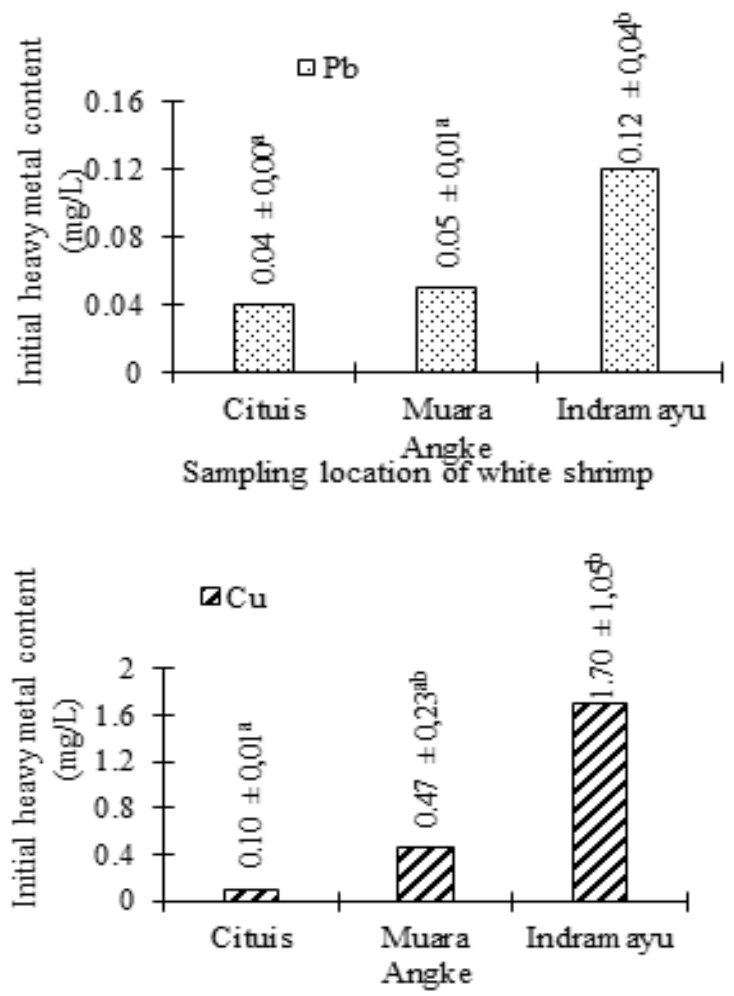

Sampling location of white shrimp

Figure 4 The initial heavy metal content of lead $(\mathrm{Pb})$ and copper $(\mathrm{Cu})$ in white shrimp samples obtained from Cituis waters, Muara Angke TPI, and Indramayu waters. Different letter notation indicates a significant difference $(\mathrm{p}<0.05)$

The acid used in the form of $\mathrm{HNO} 3(65 \%)$ and $\mathrm{H} 2 \mathrm{O} 2(30 \%)$ with a ratio of $1: 1$. The results of the destruction in the form of clear solution will be measured using an Atomic Absorption Spectrophotometer (AAS). There were four types of heavy metals that were tested initially in each sample, namely lead $(\mathrm{Pb})$, cadmium $(\mathrm{Cd})$, copper $(\mathrm{Cu})$, and chromium $(\mathrm{Cr})$.

Statistical test results between the sampling locations of the heavy metal content of copper $(\mathrm{Cu})$ in squid samples showed sig values. $\leq 0.05$, which indicates that there was a significant difference between the sampling locations and the heavy metal content of $\mathrm{Cu}$ in the sample. Based on Figure 3, squid obtained from TPI Muara Angke had the highest heavy metal $\mathrm{Cu}$ content $(1.07 \mathrm{mg} / \mathrm{L})$ compared to the other two locations. Copper heavy metal pollution in Muara Angke was caused by industrial activities located around the Muara Angke fair, such as the paint, textile, electrical equipment, and metal industries [17].

Statistical test results on the heavy metal content of $\mathrm{Pb}$ and $\mathrm{Cu}$ in white shrimp obtained from three locations showed sig values. $\leq 0.05$, which means the location of the sample affects the levels of heavy metals in the sample. Based on Figure 4, the highest $\mathrm{Pb}$ and $\mathrm{Cu}$ heavy metal content is in shrimp samples obtained from Indramayu waters with results of 0.12 $\mathrm{mg} / \mathrm{L}$ and $1.70 \mathrm{mg} / \mathrm{L}$ respectively. The life characteristics of white shrimp that can survive in polluted environments make the white shrimp accumulate heavy metals in its body $[18 ; 19]$.

\subsection{Analysis of Final Heavy Metal Content Test Results}

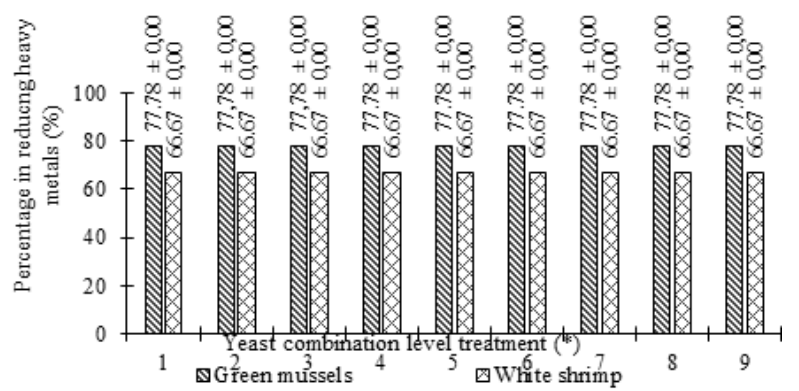

Figure 5 Percentage of reduction lead $(\mathrm{Pb})$ in green mussels and white shrimp

Information:

(*) Yeast combination level treatment:

S. cerevisiae $(100 \%)$

C. albicans $(100 \%)$

S. cerevisiae : C. albicans $(50 \%: 50 \%)$

S. cerevisiae : C. albicans $(60 \%: 40 \%)$

S. cerevisiae: C. albicans $(40 \%: 60 \%)$

S. cerevisiae : C. albicans $(70 \%: 30 \%)$

S. cerevisiae : C. albicans $(30 \%: 70 \%)$

S. cerevisiae: C. albicans $(80 \%: 20 \%)$

S. cerevisiae : C. albicans $(20 \%: 80 \%)$ 
The final metal content was carried out on selected samples which were incubated in a combination of yeast according to treatment and incubated for 24 hours at $25^{\circ} \mathrm{C}$ using a shaker. After incubation the sample was destructed using strong acids and tested with AAS. From Figure 5 it can be seen that the combination of yeast level 1 to level 9 can reduce $\mathrm{Pb}$ heavy metal content in samples of green mussels and white shrimpto $<0.04 \mathrm{mg} / \mathrm{L}$, with a reduction percentage of $77.8 \%$ for green shells and $66.7 \%$ for samples of green mussels. This showed that the nine combination yeast treatments were able to reduce the $\mathrm{Pb}$ heavy metal content in samples of green mussels and white shrimp. S. cervisiae and C. albicans were known to have the ability to accumulate cations from heavy metals, such as $\mathrm{Pb} 2+$, $\mathrm{Cu} 2+$, and $\mathrm{Zn} 2+[20]$.

Based on Figure 6 it can be seen that the highest percentage of heavy metal reduction in squid samples is in the level 4 yeast combination treatment in the form of S. cerevisiae:C. albicans (60\%:40\%), which was $94.7 \%$. In green mussels, the treatment of level 1 yeast combination in the form of S. cerevisiae (100\%) had the largest percentage reduction, which was $90.7 \%$. White shrimp samples which had the largest percentage reduction, which was $78 \%$ which was a combination of yeast $\mathrm{S}$. cerevisiae: $\mathrm{C}$. albicans (40\%:50\%).

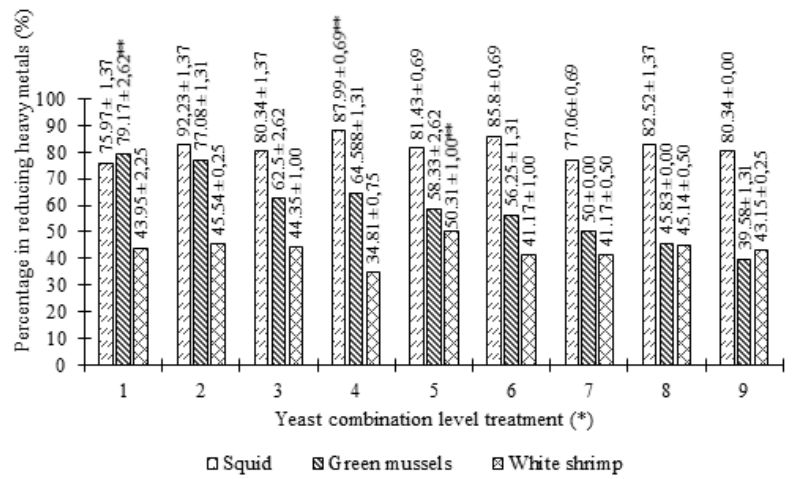

Figure 6 Percentage of reduction copper $(\mathrm{Cu})$ in squid, green mussels, and white shrimp Information:

(*) Yeast combination level treatment:

1. S. cerevisiae $(100 \%)$

2. C. albicans $(100 \%)$

3. S. cerevisiae : C. albicans $(50 \%: 50 \%)$

4. S. cerevisiae: C. albicans $(60 \%: 40 \%)$

5. S. cerevisiae: C. albicans $(40 \%: 60 \%)$

6. S. cerevisiae: C. albicans $(70 \%: 30 \%)$

7. S. cerevisiae: C. albicans $(30 \%: 70 \%)$

8. S. cerevisiae: C. albicans $(80 \%: 20 \%)$

9. S. cerevisiae: C. albicans $(20 \%: 80 \%)$

$(* *)$ The highest percentage reduction of $\mathrm{Cu}$

\subsection{Analysis of Total Yeast Resistant Heavy Metal}

The amount of yeast resistant of heavy metals was calculated using the total plate count (TPC) method on the test sample that had been added with the combination of yeast according to treatment. Statistical test results showed a difference in $\operatorname{sig}(\mathrm{p} \leq$ 0.05 ) between yeast combination treatment with the number of heavy metal resistant yeast cells in samples of squid, green mussels, and white shrimp. Combination treatment at level 4, namely S. cerevisiae: $C$. albicans with a ratio of 60\%:40\% produced the highest amount of heavy metal resistant yeast compared with other treatments.

Mixing or combining yeast with different species was very important, because each yeast had a different metabolic process that supports the entire bioremediation process. These conditions made yeast able to adapt well and were more resilient and have resistance to stressful conditions due to heavy metals $[21 ; 22]$.

\subsection{Heavy Metal Inhibition Activity Test}

The ability of yeast culture resistance to heavy metals in samples of squid, green mussels and white shrimp was tested using the well diffusion method. The PDA medium which was mixed with $5 \%$ yeast combination treatment was given three wells with a diameter of $6 \mathrm{~mm}$.

The ability of yeast combination treatment resistance in inhibiting heavy metals in the sample was considered successful if no clear zone was formed around the well containing the sample [23]. Based on the test results, it could be seen that no clear zone formed around the well containing three samples. This shows that the nine combination yeast treatments have resistance to heavy metals in the samples of squid, green mussels, and white shrimp.

\section{CONCLUSION}

The initial heavy metal content contained in squid, green shellfish and white shrimp samples obtained from Muara Angke TPI, Cituis waters, and Indramayu waters were lead $(\mathrm{Pb})$, cadmium $(\mathrm{Cd})$, copper $(\mathrm{Cu})$, and chromium $(\mathrm{Cu})$ that exceeds the maximum limit stipulated by Decree of the State Minister for the Environment (24). The largest percentage of copper reduction in squid samples was the combination of $S$. cerevisiae: $C$. albicans (60\%:40\%) by $94.66 \%$. In green mussels of $90.74 \%$ with a combination of S. cerevisiae $(100 \%)$ and in 
white shrimp using a combination of S. cerevisiae:C. albicans (40\%:60\%) of 77, 92\%. Further studies need to be done to find out heavy metal residues in yeast using fluorescence, as well as the safety of yeast used in the reduction of heavy metals in aquatic products, so that it is safe for consumption.

\section{REFERENCES}

[1] A.H. Kusuma, T. Prartono, A.S. Atmadipoera, T. Arifin, Sebaran Logam Berat Terlarut dan Terendapkan di Perairan Teluk Jakarta pada Bulan September 2014, Jurnal Teknologi Perikanan dan Kelautan 6(1) (2015) 41-49. [In Bahasa Indonesia]

[2] E. Riani, H.S. Johari, M.R. Cordova, Bioakumulasi Logam Berat Kadmium dan Timbal pada Kerang Kapak-kapak di Kepulauan Seribu, JPHPI 20(1) (2017) 131-142. [In Bahasa Indonesia]

[3] I. Hananingtyas, Studi Pencemaran Kandungan Logam Berat Timbal $(\mathrm{Pb})$ dan Kadmium $(\mathrm{Cd})$ pada Ikan Tongkol (Euthynnus sp.) di Pantai Utara, Biotropic 1(2) (2017) 41-50. [In Bahasa Indonesia]

[4] L. Fernanda, Studi Kandungan Logam Berat Timbal (Pb), Nikel (Ini), Kromium (Cr), dan Kadmium (Cd) pada Kerang Hijau (Perna viridis) dan Sifat Fraksionasinya pada Sedimen Laut, Skripsi, Universitas Indonesia, Depok, 2012. [In Bahasa Indonesia]

[5] J.X. Ilyas, Konsorsium Isolat Bakteri Resisten Logam Berat sebagai Pereduksi Logam Berat dalam Pangan Hasil Perairan Undergraduate thesis, Universitas Pelita Harapan, Tangerang, 2018. [In Bahasa Indonesia]

[6] E. Emawati, R. Aprianto, I. Musfiroh, Analisis Timbal dalam Kerang Hijau, Kerang Bulu, dan Sedimen di Teluk Jakarta, IJPST 2(3) (2015) 105-111. [In Bahasa Indonesia]

[7] T. Wahyuningsih, M. Rumanta, G. Nurdin, Pencemaran $\mathrm{Pb}$ dan $\mathrm{Cd}$ pada Hasil Perikanan Laut Tangkap Nelayan di Sekitar Teluk Jakarta. Seminar Nasional Konsercasi dan Pemanfaatan Sumber Daya Alam, 2015. SP003-015:105-111. [In Bahasa Indonesia]

[8] Jalius, D.D. Setiyanto, K. Sumantadinata, E. Riani, Y. Ernawati, Akumulasi Logam Berat dan Pengaruhnya terhadap Spermatogenesis Kerang Hijau (Perna viridis), Jurnal Ilmu-ilmu Perairan dan Perikanan Indonesia 15(1) (2008) 77-83. [In Bahasa Indonesia]
[9] S.M Indirawati, Pencemaran Logam Berat Pb dan Cd dan Keluhan Kesehatan pada Masyarakat di Kawasan Pesisir Belawan, Jurnal JUMANTIK 2(2) (2017) 54-60. [In Bahasa Indonesia]

[10] R.R. Chairiyah, H. Guchi, A. Rauf, Bioremediasi Tanah Tercemar Logam Berat Cd, $\mathrm{Cu}$, dan $\mathrm{Pb}$ dengan Menggunakan Endomikoriza. Jurnal Online Agroekoteknologi, 2(1) (2013) 348-361. [In Bahasa Indonesia]

[11] W. Bahafid, N.T. Joutey, M. Asri, H. Sayel, Naima EG. Yeast Biomass: An Alternative for Bioremediation of Heavy Metals, Chpt. 20 in "Yeast Industrial Application", ed. A. Morata and I. Loira, 2017, pp. 269-289.

[12] A.E. Febriyanti, C.N. Sari, Adisyahputra, Efektivitas Media Pertumbuhan Khamir Komersial (Saccharomyces cerevisiae) untuk Fermentasi Bioetamol dari Eceng Gondol (Eichhornia crassipes), BIOMA 12(2) (2016) 43-48. [In Bahasa Indonesia]

[13] V.K. Mutiawati, Pemeriksaan Mikrobiologi pada Candida albicans, Jurnal Kedokteran Syiah Kuala 16(1) (2016) 53-63. [In Bahasa Indonesia]

[14] A. Sharah, R. Karnila, Desmelat, Pembuatan Kurva Pertumbuhan Bakteri Asam Laktat yang di Isolasi dari Ikan Peda Kembung (Rastrelliger sp.), JOM (2015) 1-8. [In Bahasa Indonesia]

[15] T. Nurhajati, K. Soepranianondo, W.P. Lokapirnasar, Uji Aktivitas Pertumbuhan Enterobacter cloacae Selulotik Aerob Rumen-1 Isolat Asal Limbah Cairan Rumen Sapi Peranakan Ongole, Jurnal Veteriner 17(3) (2016) 383-388. [In Bahasa Indonesia]

[16] W.A. Setyati, E. Martani, Triyanto, M. Zainaludin, Kinetika Pertumbuhan dan Aktivitas Protease Isolat 36k dari Sedimen Ekosistem Mangrove, Karimunjawa Jepara, Ilmu Kelautan 20(3) (2015) 163-169. [In Bahasa Indonesia]

[17] A. Komolasari, B. Afriyansyah, M. Ihsan, M.A. Nugraha, Bioakumulasi Logam Berat $\mathrm{Pb}$ dan $\mathrm{Cu}$ terhadap Penaeus merguiensis di Perairan Teluk Kelabat Bagian Dalam, Jurnal Kelautan Tropis 22(1) (2019) 1-8. [In Bahasa Indonesia]

[18] A.R. Simbolon, E. Riani, W. Yusli, Status Pencemaran dan Kandungan Logam Berat pada Simping (Placuna placenta) di Pesisir Kabupaten Tangerang, Depik 3(2) (2015) 91-98. [In Bahasa Indonesia]

[19] W. Irawati, Y. Wijaya, S. Christian, E.S. Djojo, Characterization of Heavy Metals Resistant Yeast Isolated from Activated Sludge in 
Rungkut, Surabaya, Indonesia as Biosorbent of Mercury, Copper, and Lead. AIP Conference Proceedings, 2016. 1744(1):020061-1-020061-8.

[20] W. Irawati, A.J.N. Parhusip, S. Christian, T. Yuwono, The Potential Capability of Bacteria and Yeast Strains Isolated from Rungkut Industrial Sewage in Indonesia as a Bioaccumulators and Biosorbens of Copper, Biodiversitas 18(3) (2017) 971-977.

[21] E. Ilhan, D. Ozuolmez, A. Çotuk, N. Cansever, G. Muyzer, Isolation of a Sulfide-Producing Bacterial Consortium from Cooling-Tower Water: Evaluation of Corrosive Effect on GAlvanized Steel, Anaerob 43(17) (2016) 2734.

[22] S. Fatimah, F. Nadifah, I. Burhanudin, Uji daya Hambat Ekstrak Etanol Kubis (Brassica oleracea var. Capitate f. alba) terhadap Bakteri Staphylococcus aureus secara In Vitri, Biogenesis 4(2) (2016) 102-106. [In Bahasa Indonesia]

[23] Keputusan Menteri Negara Lingkungan Hidup, KeputusanMenteriNegara Lingkungan Hidup No mor 51 Tahun 2004 tentang Baku Mutu Air Laut . Indonesia, 2004. [In Bahasa Indonesia] 